\title{
HALINA KORBICZ
}

Uniwersytet im. Adama Mickiewicza w Poznaniu

Wydział Neofilologii

\section{POEZJA ZZA KRAT}

Щоб промінь волі не погас: вірші украйнських поетів у перекладі російською мовою Марка Каганцова - Чтоб луч свободы не погас: стихотворения украинских поэтов в переводе на русский язык Марка Каганцова, упоряд. і автор передмови Р. Кюнцлі, Українські технології, Львів 2015, сс. 576. Ŝb promìn' volì ne pogas: vìršì ukraïns'kih poetìv u perekladì rosìjs'koû movôu Marka Kagancova. - Ćtob luč svobody ne pogas: stihotvoreniâ ukrainskih poètov v perevode na russkij âzyk Marka Kagancova, uporâd. ì avtor peredmovi R. Kiunclì, Ukraïns'kì tehnologiï, Lvìv 2015, ss. 576.

Obywatelski sprzeciw ukraińskiej elity intelektualnej wobec systemu totalitarnego znalazł swój wyraz w wielu świadomych i konsekwentnych formach. Wciąż jeszcze trwają studia nad nimi oraz wprowadzanie ich do obiegu naukowego. Unikalnym zjawiskiem był niewątpliwie samizdat, po ukraińsku - samwydaw, który jako wytwór powojennego społeczeństwa stał się gwarancją wolności słowa w ZSRR, bezsprzecznym dowodem na to, że słowo drukowane można rozpowszechniać pomimo cenzury. Masowy kolportaż „produkcji” samwydawu, efekt nie tylko wolnomyślicielstwa czy bezinteresowności, nie tylko protestów i opozycyjnej postawy, lecz także walorów intelektualnych, sprawił, że całościowe ujmowanie tego zjawiska jest dziś nadzwyczaj trudne i prawie niemożliwe. Podjęto już pierwsze, cząstkowe próby takich badań ${ }^{1}$. Jednak w celu kompleksowego przedstawienia i obiektywnego omówienia wszystkich form ukraińskiego undergroundu potrzeba zapewne zarówno dystansu czasowego, jak i ujawnienia nieznanych dotąd faktów oraz dokumentów, których uwzględnienie byłoby nie mniej istotnym warunkiem wstępnym.

Istotnym uzupełnieniem naszej wiedzy o działalności twórczej w strukturach opozycyjnych może stać się tom wierszy ukraińskich więźniów politycznych Щоб промінь волі не nozac (By nie zgast promień wolności). Zaprezentowano tu ponad stu autorów. Niektórym $\mathrm{z}$ nich udawało się przekazywać swoje wiersze na wolność, publikowano je w drugim obiegu; na Zachodzie ukazały się tomy utworów poetyckich Wasyla Stusa i Ihora Kałyn-

${ }^{1}$ G. Kasianov, Nezgodni: ukrajins'ka inteligencija v rusi oporu, Kyiv 1999; O. Obertas, Ukrajins'kyj samvydav, Kyiv 2010. 
cia, jednak nazwiska zdecydowanej większości autorów tomu pozostawały niezbyt znane lub zgoła nieznane zupełnie. Podziw wzbudza dziś sam fakt zachowania tych utworów, pośród setek innych, zniszczonych przez funkcjonariuszy aparatu represji. A jeszcze bardziej godne podziwu jest to, że napisano je w zatrważających warunkach ustawicznego nieomal nadzoru i bezwzględnego okrucieństwa z jednej strony oraz całkowitej bezbronności z drugiej.

Pod względem chronologicznym powstanie utworów przypada na okres zaczynający się w drugiej połowie lat 40. XX wieku, zakończony uzyskaniem niepodległości przez Ukrainę, są tu także wiersze wspomnieniowe datowane na lata 90. Wszystkie odzwierciedlają specyfikę sytuacji ukraińskiej, w której opozycja polityczna i kulturowa stanowiły dwa aspekty tego samego fenomenu. Ukraińscy więźniowie polityczni stanęli przed koniecznością stworzenia własnej przestrzeni kulturowej, alternatywnej wobec oficjalnej, oraz zażywania wolności w słowie, jakiej wzbraniano im w codziennym życiu.

Choć celem redaktorów tomu nie było selekcjonowanie wierszy ze względu na czas ich powstania, nader odczuwalna jest tu dynamika pokoleniowa. Jednak być może najbardziej uderzające jest następstwo tematyczne. Pieśni historyczne czy dumki kozackie jako kolektywna twórczość ludowa czasów ucisku, niewoli i cierpień na obczyźnie znajdują oddźwięk w poezji Tarasa Szewczenki z okresu dziesięcioletniego zesłania, w wierszach skazanego na dożywotnie zesłanie Pawła Hrabowskiego, w metaforyce cyklu Невольничі пісні (Ріеśni niewolnicze) Łesi Ukrainki, w tomie poezji Ihora Kałyncia Невольнича муза (Niewolnicza muza) itd. Ze względu na emocjonalność, utwory o proweniencji folklorystycznej i literackiej kreślące obrazy niewoli niosą w sobie również motywy sprzeciwu wewnętrznego wobec niekorzystnych okoliczności życiowych. Daje to świadectwo hartowania woli, kształtowania się nie tylko ludzkich charakterów, lecz także samej literatury. Poeci-dysydenci, przebywając z dala od ojczyzny, uwięzieni w obozach lub zesłani na Ural Północny, Koło Podbiegunowe, do Republiki Komi, Kołymy, Mordowii czy obwodu Magadańskiego, kontynuują charakterystyczną dla kultury ukraińskiej tradycję relacji z obczyzną, rozwijając i wzbogacając jej główne symptomy osobistym doświadczeniem życiowym.

Wiersze lat 40. i 50. odzwierciedlają idee nieodległych czasowo walk narodowowyzwoleńczych, zarówno przeciw nazistowskiej, jak i radzieckiej okupacji. Uczucia patriotyczne, powodujące ludźmi walczącymi o niepodległość, sublimują się w twórczości i przenoszą na strofy poezji. Jest to przeważnie poetycka publicystyka.

Na zrębie dwóch światów czas do boju stanąć,

Na zrębie dwóch epok wschodzi świat szlachetny.

Oko w oko: Naród z ciżbą nieprzebraną,

Dokoła nieprzyjaciół - żywopłot spleciony ${ }^{2}$.

На скресі двох світів стаємо до двобою,

На скресі двох епох гряде шляхетний світ.

Віч-на-віч Нація з безликою юрбою.

Навколо ворогів - суцільний живопліт.

(Anatolij Łupynos, bez tytułu, s. 395).

\footnotetext{
${ }^{2}$ Tu i dalej tłumaczenie z języka ukraińskiego dr Marcina Gaczkowskiego, któremu wyrażam podziękowanie - H.K.
} 
Rzecz jasna, takie utwory poetyckie nacechowane są politycznym zaangażowaniem i patriotycznym patosem. Jednak nawet $\mathrm{i} w$ tych ramach każdy $\mathrm{z}$ poetów, $\mathrm{z}$ większym lub mniejszym talentem, odnalazł własną intonację, która współgra $z$ ówczesną epoką i jej wydarzeniami. Głosy autorów wybrzmiewają niczym głos zbiorowy reprezentujący tych Ukraińców, którym obce były kompromisy, którzy nie podjęli żadnej współpracy z reżymem radzieckim, którzy zdołali dostrzec jego prawdziwą, totalitarną istotę i przewidzieli jego upadek. Nawet w odległych latach 40. i 50., gdy w społeczeństwie utrzymywało się jeszcze zaufanie do partii komunistycznej z jej skażoną quasi-optymizmem ideologią, poeci-więźniowie polityczni przejawiali prowidencjalistyczną wrażliwość, wskazując, że reżym komunistyczny dokonał niezliczonych, celowych zbrodni przeciw ludzkości. Oznaczało to, że nowe są tylko kwestią czasu:

A cóż potomnym wy pozostawicie już po haniebnym swoim krachu? Jedynie trupów tajemne piwnice, milczących świadków cierpień i strachu.

Що ж нащадкам залишите після свого ганебного краху?

Тільки трупів таємні рови, в яких свідки страждання і жаху.

(Mychajło Łucyk, bez tytułu, s. 397).

Poeci nie tracili zdolności do bezbłędnego prognozowania politycznego, często wbrew uspokajającym bądź ambiwalentnym nurtom opinii publicznej.

Wszystkie utwory przenika nadzwyczajny, niemal archetypiczny, stosunek do Ukrainy jako matki-ziemi. Wyrażono tu całą gamę uczuć, umieszczonych w szerokim spektrum przejawów i ukrytych w kontekstach:

Jeszcze wystarczy nam życia na to szczęście,

Powrócić i umrzeć na własnej ziemi

Ще того віку вистачить для щастя

Прийти і вмерти на своїй землі

(Ірина Калинець, Ще того віку вистачить..., s. 68).

a także jawnych, zadeklarowanych:

Mój losie, Ukraino moja,

Gdybyś ty wewnątrz mnie nie żyła,

Mój trup już dawno zła zawieja

W pustkowiu śniegiem by okryła

Моя ти доле, Україно.

Якби ти в мені не жила

Давно б мій труп зла хуртовина

В пустелі снігом замела

(Jewhen Czerednyczenko, Якби не ти, моя Вкраїно, s. 347).

Obraz Ukrainy nie tylko przenika cały tom, stanowi również jego twórczą dominantę psychologiczną. Ukraina nie jest „nieszczęśliwą wdową” wedle personifikacji Szewczenki, 
„matką nieszczęsną” (Łesia Ukrainka), lecz matką, w której obronie i z myślą o przyszłości której powstaną nowe pokolenia Ukraińców. Oddanie Ukrainie ma nie tylko emocjonalne, lecz również ideologiczne uzasadnienie: mimo kolosalnego dystansu dysydenci znali efektywność mechanizmu totalnej rusyfikacji zorientowanej na niwelowanie tożsamości ukraińskiej (ataki na język, oświatę, religię), dążyli zatem do wielostronnego utwierdzenia definiowanego narodowo wizerunku swej ojczyzny, dostrzegając w tym rękojmię istnienia narodu.

Wiersze charakteryzują się dokumentalizmem. Z zapisu bieżących wrażeń wyłaniają się realia życia obozowego z jego okrucieństwem, brutalnością, a w najlepszym wypadku bezmyślną monotonią. A przecież i w tych ekstremalnych warunkach autorzy potrafili dostrzec Człowieka i wynieść go ponad barbarzyńskie okoliczności, zaświadczając tym samym o wysokich walorach moralnych ukraińskiego poety, który, będąc więźniem politycznym, nie jest i nie zostanie więźniem sumienia. Jak, na przykład, w wierszu Iwana Sawycza Останню напружу силу (Ostatki wytężę sit), gdy imperatyw moralny dyktuje etykę zachowania, a także determinuje odpowiednią estetykę. W przemarzłej ziemi gułagu, gdzie zaznały wiecznego odpoczynku tysiące skazanych osób, bezsilni więźniowie kopią bratnią mogiłę, kiedy nagle pośród umarłych, których będą chować, odnajdują zwłoki młodej dziewczyny:

Jej ledwie dziewiętnasty. Boże, Jak wcześnie przecięto nić...

Nie godzi się, myślim, nie może

W mogile z chłopcami jej być.

Nie godzi! Więc siły krzeszem, Ryjemy zmarzłość przeklętą,

By naszą mileńką siostrę,

Pochować, niczym świętą.

Їй лиш дев'ятнадцятий. Боже,

Як рано обірвано путь...

Не можна, гадаєм, не гоже

В могилі їй 3 хлопцями буть.

Не гоже! Знаходимо силу,

Довбаємо ще мерзлоту,

Щоб нашу сестриченьку милу

Ховати, неначе святу.

(s. 309-311).

Opieranie się relacjach zaufania sprawia, że liryka zyskuje na autentyzmie i wiarygodności. Z kolei intencja poety, by mówić i słyszeć rzeczy prawdziwe, gwarantuje mu wyjście z „niemej niewoli”, budzi odwagę bycia sobą, żywienia własnych przekonań i ich obrony. Zawarte w wierszach obserwacje podważają zasady oficjalnej ideologii oparte na fałszu, demagogii i cynizmie, wysuwając alternatywę dla nich - prawdę artystyczną, stającą się jednocześnie prawdą historii.

Świadomość twórcza przydawała sztuce wolności wewnętrznej, ustanawiała dystans wobec represyjności władz, wobec okoliczności życia w niewoli, wobec przynależności 
geograficznej. Przebywanie (rzucenie w świat) człowieka w takich miejscach, pomimo jego woli i wyboru, nie wykluczało aktywności ludzkiej, przeciwnie - raczej ją wywoływało. Zademonstrowała to dobitnie ukraińska inteligencja pokolenia lat 60., tzw. sześćdziesiątnicy (szistdesiatnyky). Jak wiemy, byli oni pierwszymi, którzy wszczęli świadomy bunt przeciwko systemowi, dając tym samym impuls do odnowienia ukraińskiej kultury, zarówno ówczesnej, jak i przyszłej. W duchu filozofii egzystencjalizmu (Jaspers, Camus) pokolenie lat 60. ustanowiło odpowiedzialność człowieka przed społeczeństwem oraz przed samym sobą, podniosło problem indywidualnego wyboru ujawniającego tożsamość moralną człowieka. Fenomen pokolenia lat 60 . budził wiarę w ludzką godność. Zdaniem filozofa i byłego dysydenta Myrosława Marynowycza „godność oznacza zrzucenie z własnej duszy reżymu autorytarnego. Godność to pewność, że jesteśmy w stanie zorganizować życie zgodnie z wymaganiami naszego wewnętrznego świata"3.

Znalazłszy się za więziennymi drutami, plejada twórców (a pośród nich postaci dla ukraińskiej kultury reprezentatywne: Wasyl Stus, Iwan Switłycznyj, Jewhen Swerstiuk, Ihor Kałyneć, Mykoła Rudenko i wielu innych) nie zmieniała i nie korygowała swoich przekonań, przeciwnie - rozwijała je w nowych warunkach. Doświadczenie egzystencjalne zostało pogłębione o odosobnienie. Odosobnienie, jak w Palimpsestach Stusa, to nie tylko przeżycia osobiste, lecz również grupowe, a także kategoria ogólnoludzka lub filozoficzna ${ }^{4}$. Obrazy życia obozowego zaostrzały odczucia wewnętrzne, w których narastający konflikt wolnej osobowości z zaprogramowanymi przez radziecki system wykonawcami umacniał się o niepodważalną konkretyzację. Dobrym przykładem jest Szmon (w radzieckim żargonie więziennym 'rewizja', 'kipisz') z wiersza Iwana Switłycznego.

Tak jak mnie matka urodziła

Bez gatek i bez portek stoję,

Niby Apollo grecki prawie,

Bezwstydny. A towarzysz bez mydła

Usta $\mathrm{i}$ anus bada mi rzetelnie

Baczy, sukinsyn, żeby nie uwiła

Siedliska buntu ta zaraza we mnie

Kipisz to kipisz. Takije dieła!

Стою - як мати народила:

Без трусиків, без панталон,

Точнісінько, як Аполлон

Безличний. А сержант без мила

Поліз у рот, у афедрон,

Пильнує, стерво, щоб бацила

Антирежимності не звила

Гнізда крамоли. Шмон є шмон.

(s. 42).

Lub w wierszu Stusa bez tytułu Невже ти народився, чоловіче... (Czyżbyś narodził się, człowiecze...), gdzie mowa o starciu postaci lirycznej z więziennym nadzorcą:

\footnotetext{
${ }^{3}$ M. Marynovych, ,Hidnist' - ce skynuty avtorytarnyj rezhym zi svojeji dushi”, 2014, http://old.dyvensvit. org/articles/103539.html (5.02.2017).

${ }^{4}$ Y. Shevelov, Trunok i trutyzna (Pro „Palimpsesty” Vasyla Stusa), [w:] Y. Shevelov, Vybrani praci. Literaturoznavstvo, uporiadnyk I. Dziuba, Kyiv 2009, Knyha II, s. 1047.
} 
Jam dobro. Tyś jest proch i pył.

A to co wspólne - my więźniami obaj.

Drzwi obie strony. Tam ty, a tu ja.

Nas różnią mury niby regulamin.

Я є добро. А ти - труха і тлінь.

А спільне в нас - що в'язні ми обоє.

Дверей оба боки. Ти там, я - тут.

Нас порізнили мури, як статут.

(s. 52).

Wszystkim autorom tomu należy oddać zasługę wprowadzenia do sfery literatury człowieka-więźnia. Jawi się on zarówno jako obraz literacki, jak i figura stylistyczna, napełniając jedno i drugie siłą własnych emocji. To właśnie przedstawiciele pokolenia lat 60., przyczyniając się do odrodzenia wewnętrznego ludzkiego świata, udowodnili, że człowiek zmartwychwstał za sprawą swego buntu.

Systematycznie, wiersz za wierszem, odmalowuje się w książce obraz wieloletniej walki nonkonformistycznej inteligencji o ideały, z których wiele stało się już dziś powszechnymi. Zaś ruch oporu, zapoczątkowany w latach 60., a kontynuowany w 70. i 80., w licznych swoich przejawach stanowił zamknięcie bez mała stuletniej ewolucji polityczno-duchowej ukraińskiej inteligencji, podsumowanie rozwoju i ideowej tradycji.

Wydanie zrealizowano jako dwujęzyczne - wiersze prezentowane są równolegle po ukraińsku oraz w przekładzie na język rosyjski znanego tłumacza poezji ukraińskiej Marka Kagancowa. Redaktorka tomu, Romana Kiuncli, sens opracowania bilingwalnej książki wyjaśnia próbą ,przebicia się do rosyjskiej przestrzeni informacyjnej ze względu na jej jednostronność w opisie wydarzeń związanych z ukraińską walką o wolność, przez władze rosyjskie przedstawianych jako nacjonalizm"5. Zdaniem Kiuncli rozpowszechnianie poezji osób walczących o wolność Ukrainy jest ważne w celu uświadomienia rosyjskojęzycznemu światu, że „działaniami Ukraińców powodowały nie nienawiść do obcego języka, kultury czy narodu, lecz miłość do ziemi ojczystej”' Zadanie, które postawili przed sobą redaktorzy tomu, stanowi jego dodatkowy atut obok mrówczej pracy wykonanej przez nich w celu opracowania pierwszego systematycznego zbioru poezji obozowej.

\section{Bibliografia}

Kasianov G., Nezgodni: ukrajins'ka inteligencija v rusi oporu, Kyiv 1999.

Kiuncli R., Vid uporiadnyka. Schob promin'voli ne pohas, Lviv 2015, s. 3-34.

Marynovych M., ,,Hidnist' - ce skynuty avtorytarnyj rezhym zi svojeji dushi”, 2014, http://old.dyvensvit.org/articles/103539.html (5.02.2017).

Obertas O., Ukrajins 'kyj samvydav, Kyiv 2010.

Shevelov Y., Trunok i trutyzna (Pro „Palimpsesty” Vasyla Stusa), [w:] Y. Shevelov, Vybrani praci. Literaturoznavstvo, uporiadnyk I. Dziuba, Kyiv 2009, Knyha II, s. 1040-1075.

\footnotetext{
${ }^{5}$ R. Kiuncli, Vid uporiadnyka. Schob promin' voli ne pohas, Lviv 2015, s. 4.

${ }^{6}$ Ibidem, s. 5.
} 
